\title{
4. 欧米のケーブルモデム事情
}

\section{1. ま え がき}

CATVの普及率の高い欧米, 特にアメリカでは, 当初予定の約 1 年半遅れでケーブルモデムサービスが 立ち上りつつある。これには以下のような背景があ る.すなわち, 1970 年代から 1980 年代のディジタル 信号処理と継続した半導体技術の進歩によって CATVを用いた高速デー夕通信が可能となってきた こと, また, 幹線に光ファイバ, 支線に同軸ケーブル を用いる HFC (Hibrid Fiber/Coax) 技術が発展した ことで, 双方向の広带域通信が実現しつつあることで ある。そこへインターネットの急成長が重なったこと から CATV は, もはや単なるアナログの映像配信入 ディアとしてではなく, ディジタルの高速・広带域の 通信インフラとして見直されてきた。そして法的にも アメリカの新電気通信法である Telecom Act of 1996 や, 日本政府による CATV 事業の事業範囲や, 外資 規制に対する規制緩和によって，従来は有線テレビジ ヨン放送メディアとして考えられてきた CATVこそ が, 通信, 放送, さらにコンピュータネットワークを 融合する新たなネットワークの有力な候補としての地 位を築きつつあるといえる。

本稿では，CATVを用いた高速インターネットの キーコンポーネントであるケーブルモデムについての 歴史, 技術的要点, そして市場動向について述べる.

\section{2. ケーブルモデムの発展経緯}

ケーブルモデムは, 1980 年代初頭のブロードバン ドLAN が起源となっている。すなわち，1981 年か ら 1982 年にかけて開発されたものが最初である。こ れが,アメリカ国防総省のプロジェクトであり, Wang Laboratories 社と MIT の Lincoln Labs との

†株式会社グラフィックス・コミュニケーション・ラボラト リーズ 研究開発本部

"Status of Cable Modem Services in Europe and the USA" by Hiroshi Fujiwara (R \& D Headquarters, Graphics Communication Laboratories, Tokyo)
正会員 藤 原

洋 $^{\dagger}$

共同開発によるWang Netである. 当システムは, ベースバンド伝送を行う Ethernet と比較して, 約 60 $\mathrm{km}$ にも及ぶ長距離伝送を可能とした. 1985 年には, システムは Wang 社内で約 6000 台のミニコンピュー 夕に拡張され, ちょうどこの頃, 当プロジェクトに参 加し始めた Applitek 社が DEC 社内のブロードバン ドネットワーク構築を 1980 年代の後半に実現した.

このApplitek 社は, 1990 年に LANcity 社に社名 変更し, より積極的な活動を開始した. 現在まで, こ のケーブルモデムのパイオニアともいえる多くの実績 をもっている.そして, 1996 年に大手 LAN /ルー タ・ベンダの Bay Networks 社に買収され同社の一 事業部門になった。

Zenith 社は 1990 年頃, 高周波技術を活かした対称 型モデムの開発を始め, Ethernet プロトコルに準拠 した $500 \mathrm{~kb} / \mathrm{s}$ の対称型モデム, 続いて $4 \mathrm{Mb} / \mathrm{s} の$ 高 速型を開発している。

同じ頃, IBM 社から独立したエンジニアを中心に， 1990 年にベンチャーキャピタルなどの支援を得て Hybrid Networks 社が設立された。1993 年に同社は 世界初の非対称型モデムを完成させ，次世代の基礎を 作った。この間, VOD(Vide On Demand)ブームがあ り，ケーブルモデム技術は映像信号の配信技術として も発展した。

このように, LANcity 社, Zenith 社, Hybrid Network 社など先駆的なベンチャー企業による摇籃 期を第 1 世代と呼ぶことにする(図 1 参照).

さて, 広域 LAN システムとして, 最初はLANcity などの対称型モデムが実績を上げたが，昨今で は, WWWサービスと CATVのチャンネル構成 （帯域幅は上りが狭く，下りが広い）に適した非対称 型が登場し, 非対称型の Web 基本とするインター ネットという新たな市場形成によって, 1990 年代半 ばには非対称型が主流となっている。この第 2 世代に は, Hewlett Packard 社, Motorola 社, Com 21 社 などが知られている。第 2 世代製品は, ネットワーク 管理やルーティング制御などのシステム化を指向して 


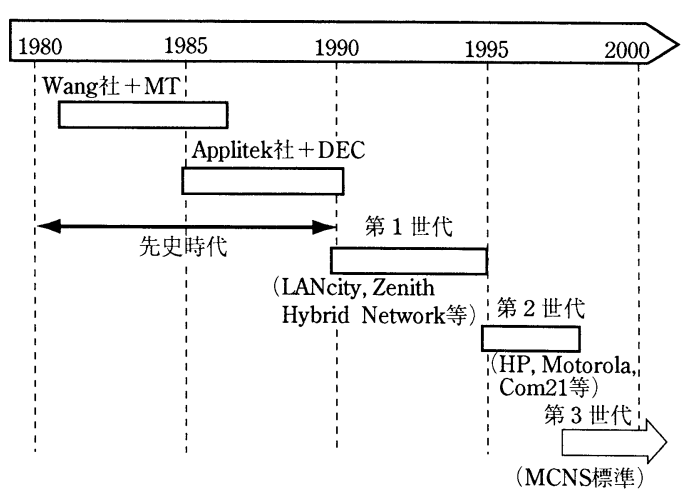

図 1 ケーブルモデムの世代交代

おり，ケーブルモデムベンダとコンピュータネットワ ークベンダとの連合が進行している．例をあげると， Motorola と SunMicrosystems, LANcity と BayNetworks, Com 21 と 3 Com, Trayan と CiscoSystems などの提携がある。その後, HP 社, IBM 社, First Pacific Network 社は, 1997 年 3 月〜 5 月にかけて事 業撤退を決めている。

今日では, 第 2 世代のケーブルモデム製品は 20 社 以上にのぼり (表 1 参照), 今後は第 3 世代の標準化対 応製品へと移行していくものと考えられる。

\section{3. ケーブルインターネットのシステム構成}

以上に述べたケーブルモデムの登場という技術的な 面だけでなく，ケーブルインターネットへと発展した いくつかの背景がある.この背景としては, 以下の 4 点に集約することができる。

(1)アメリカにおける新電気通信法であるTelecommunications Act of 96 (Telecom Act 96)の 施行による法制度上の規制緩和。

(2) 1990 年代前半 VOD ブームにより，ディジタル 映像の配信技術としてケーブルモデム技術が発展 した。

(3)インターネットの急速な普及と高速アクセス回 線という市場からの要請.

(4) ディジタル信号処理と半導体技術の発展による ケーブルモデムの低コスト化という技術面での進 歩.

先に述べたように，Telecom Act 96 や日本政府の 規制緩和で, CATV オペレータは, ほとんど無条件 にデー夕通信事業に参入することができるようになっ た。そして, 今日ではVOD ブームが沈静化したが, インターネットの爆発的な発展によって, 特に電話網
に依存してきたアクセス回線の容量不足の問題が浮き 上がってきた。このボトルネックの解消の最も現実的 な手段として登場したのがケーブルモデムである.

ケーブルモデムの中心的な技術となっている 64 $\operatorname{QAM}(64$ 值の直交振幅変調)の技術(図 2 参照) は, 従来から理論的には確立していたが, $6 \mathrm{MHz}$ 带域で $30 \mathrm{Mb} / \mathrm{s}$ の伝送速度を実現するようになったのは， 年々進歩を続ける半導体技術によっている.

このような変復調技術を基本として構築される典型 的なシステムでは, 図 3 に示すように, 加入者宅には $\mathrm{PC}$ と $10 \mathrm{BASE}-\mathrm{T}$ で接続されるケーブルモデムを設 置する.そして, 双方向の HFC (Hybird Fiber) Coax, 光ファイバ・同軸ケーブルの混在システム)を 用いるか,または旧式のCATVでは,下りには CATVを用い, 上りには電話回線を用いる.

1 台の光ファイバ・HUB ノード(ここで光ファイバ 幹線と末端の同軸ケーブルのネットワークとが結合さ れる)で, 約 500〜2000 軒がサポートされる.そして， ヘッドエンドまたは, 分散 HUB に設置されるへッド エンドモデム, サーバ, ルータ, および各種の管理シ ステムや運用支援システムなどで構成される。

ここで特にへッドエンド側のシステムが重要で, 次 のような構成となっている。

狭い範囲にサービスしている独立したへッドエンド は, 今日, 几長性のある光ファイバリングによって相 互に接続される傾向にある。これは，1カ所のサイト でグループ化された多くの機能を共有できることを意 味し，このサイトはマスタヘッドエンドと呼ばれる.

マスタヘッドエンドとして設計されたサイトは，何 よりもまず，インターネットポイントオブプレゼンス $(\mathrm{PoP})$, すなわち, ケーブルシステムが, 高速のイン ターネットバックボーンに接続するポイントとして機 能する. 小規模なケーブルシステムにとっては, 直 接, 自前のバックボーンに接続するのではなく, MCI などのインターネットアクセスプロバイダを通 じて接続した方が経済的である．地域リングを構築す ることで, マスタヘッドエンドとインターネット PoP は, 都市域全体にサービスすることができる.

マスタヘッドエンドの最初の装置群および機能セッ トは，マスタヘッドエンドを構成するコンピュータ群 と外部のインターネットバックボーンの間でデータ／ ストリームを渡すスイッチング装置類である。

IP ルータやサイト中央ルータ, 企業用ルータなど, さまざまな用途に利用されるこの装置は, 外部のイン ターネットとケーブルシステムの間のインタフェース となる。 
表 1 主なケーブルモデム製品 ${ }^{2)}$

\begin{tabular}{|c|c|c|c|c|c|}
\hline Vendor & Product & Downstream & Upstream & Partners & Trials/Orders \\
\hline $3 \mathrm{Com}$ & $\begin{array}{l}3 \text { Com Cable } \\
\text { Modem }\end{array}$ & $\begin{array}{l}30 \mathrm{Mbps} \text { per } 6 \mathrm{MHz} \\
\text { with } 64 \text { QAM }\end{array}$ & $\begin{array}{l}2.6 \mathrm{Mbps} \text { per } 6 \\
\mathrm{MHz} \text { with QPSK }\end{array}$ & Com 21 & Trials planned for Q 21997 \\
\hline $\begin{array}{l}\text { Bay } \\
\text { Networks }\end{array}$ & LANcity LCP & $\begin{array}{l}10 \mathrm{Mbps} \text { per } 6 \mathrm{MHz} \\
\text { with QPSK }\end{array}$ & $\begin{array}{l}10 \mathrm{Mbps} \text { per } 6 \mathrm{MHz} \\
\text { with QPSK }\end{array}$ & $\mathrm{C}-\mathrm{COR}$ & $\begin{array}{l}\text { More than } 41,000 \text { LANcity } \\
\text { modems in the field. Pur- } \\
\text { chases include Continental } \\
\text { for } 50,000 \text { units and Cox for } \\
35,000 \text { units }\end{array}$ \\
\hline Com 21 & ComPORT & $\begin{array}{l}\text { 30 Mbps per } 6 \mathrm{MHz} \\
\text { with } 64 \text { QAM }\end{array}$ & $\begin{array}{l}2.6 \mathrm{Mbps} \text { per } 6 \\
\mathrm{MHz} \text { with QPSK }\end{array}$ & $3 \mathrm{Com}$ & $\begin{array}{l}\text { Trails with Prime Cable and } \\
\text { Cablecom of Zuerich }\end{array}$ \\
\hline $\begin{array}{l}\text { First Pacific } \\
\text { Networks }\end{array}$ & FPN 3000 & $\begin{array}{l}10 \text { Mbps per } 6 \mathrm{MHz} \\
\text { with AMPSK }\end{array}$ & $\begin{array}{l}10 \mathrm{Mbps} \text { per } 6 \mathrm{MHz} \\
\text { with SQPSK }\end{array}$ & & $\begin{array}{l}\text { Vendor for trails by Pacific } \\
\text { Gas \& Electric, EPB Network } \\
\text { System (Kentucky) }\end{array}$ \\
\hline $\begin{array}{l}\text { General } \\
\text { Instrument }\end{array}$ & SURFboard & $\begin{array}{l}30 \mathrm{Mbps} \text { per } 6 \mathrm{MHz} \\
\text { with } 64 \text { QAM }\end{array}$ & Telco return & $\begin{array}{l}\text { FORE } \\
\text { Systems }\end{array}$ & $\begin{array}{l}\text { Continental purchased } 10,000 \\
\text { units }\end{array}$ \\
\hline Heyes & $\begin{array}{l}\text { ULTRA Cable } \\
\text { Modem }\end{array}$ & $\begin{array}{l}5 \mathrm{Mbps} \text { per } 6 \mathrm{MHz} \\
\text { with FSK }\end{array}$ & Telco return & & $\begin{array}{l}\text { Trails scheduled for Q } 11997 \\
\text { with commercial availability } \\
\text { in Q } 2\end{array}$ \\
\hline $\begin{array}{l}\text { Hewlett- } \\
\text { Packard }\end{array}$ & QuickBurst & $\begin{array}{l}30 \mathrm{Mbps} \text { per } 6 \mathrm{MHz} \\
\text { with } 64 \text { QAM }\end{array}$ & $\begin{array}{l}1.5 \text { to } 3 \text { Mbps per } \\
2 \mathrm{MHz} \text { with } \\
\text { BPSK/QPSK }\end{array}$ & & $\begin{array}{l}\text { Order for up to } 150,000 \\
\text { modems from Comcast and } \\
\text { pending deal with Cox }\end{array}$ \\
\hline $\begin{array}{l}\text { Hybrid } \\
\text { Networks }\end{array}$ & $\begin{array}{l}\text { Remote Link } \\
\text { Adapter } \\
\text { Model } 211\end{array}$ & $\begin{array}{l}30 \mathrm{Mbps} \text { per } 6 \mathrm{MHz} \\
\text { with } 64 \text { QAM }\end{array}$ & $\begin{array}{l}512 \text { kbps per } 300 \\
\mathrm{kHz} \text { with } 2,4 \text {, and } \\
8 \mathrm{VSB}\end{array}$ & $\begin{array}{l}\text { Sharp, } \\
\text { Itochu, } \\
\text { Alcatel }\end{array}$ & $\begin{array}{l}\text { Vendor with Intel for Viacom } \\
\text { trial Castro Valley and Com- } \\
\text { cast trial in Lower Merion, } \\
\text { PA. }\end{array}$ \\
\hline IBM & $\begin{array}{l}\text { Cable Online } \\
\text { Access System }\end{array}$ & $\begin{array}{l}30 \mathrm{Mbps} \text { per } 6 \mathrm{MHz} \\
\text { with } 64 \text { QAM }\end{array}$ & $\begin{array}{l}2 \mathrm{Mbps} \text { per } 1.8 \\
\mathrm{MHz} \text { with QPSK }\end{array}$ & & $\begin{array}{l}\text { Trials scheduled for Q } 11997 \\
\text { with commercial availability } \\
\text { by mid-year for ATM sys- } \\
\text { tem. }\end{array}$ \\
\hline Intel & CablePort & $\begin{array}{l}30 \mathrm{Mbps} \text { per } 6 \mathrm{MHz} \\
\text { with } 64 \text { QAM }\end{array}$ & Telco return & & $\begin{array}{l}\text { Limited commercial availa- } \\
\text { bility in Q } 11997 \text { with volume } \\
\text { shipments in second half of } \\
\text { the year }\end{array}$ \\
\hline Motorola & $\begin{array}{l}\text { Cyber } \\
\text { SURFR }\end{array}$ & $\begin{array}{l}30 \mathrm{Mbps} \text { per } 6 \mathrm{MHz} \\
\text { with } 64 \text { QAM }\end{array}$ & $\begin{array}{l}768 \text { kbps per } 600 \\
\text { kHz with } \pi / 4 \\
\text {-DQPSK }\end{array}$ & $\begin{array}{l}\text { Cascade, } \\
\text { Sun }\end{array}$ & $\begin{array}{l}\text { Orders for } 500,000+\text { modem } \\
\text { units from Time Warner } \\
\text { Cable, Cox, Comcast, TCI, } \\
\text { and others. }\end{array}$ \\
\hline NEC & CM 5000 & $\begin{array}{l}30 \mathrm{Mbps} \text { per } 6 \mathrm{MHz} \\
\text { with } 64 \text { QAM }\end{array}$ & $\begin{array}{l}2 \mathrm{Mbps} \text { per } 1.5 \\
\mathrm{MHz} \text { using QPSK }\end{array}$ & & $\begin{array}{l}\text { Trials in February } 1997 \text { in } \\
\text { Japan with commercial avail- } \\
\text { ability in mid-1997 }\end{array}$ \\
\hline NetGame & NeMo & $\begin{array}{l}6 \mathrm{Mbps} \text { per } 6 \mathrm{MHz} \\
\text { with MSK }\end{array}$ & $\begin{array}{l}1.5 \mathrm{Mbps} \text { per } 1.5 \\
\mathrm{MHz} \text { with MSK }\end{array}$ & & $\begin{array}{l}500 \text {-user trial in Tel Aviv } \\
\text { with Tevel, Israel's largest } \\
\text { cable operator. }\end{array}$ \\
\hline $\begin{array}{l}\text { New Media } \\
\text { Comm. }\end{array}$ & CyberCity & $\begin{array}{l}5.5 \text { Mbps per } 6 \\
\text { MHz channel using } \\
\text { ASK }\end{array}$ & Telco return & & $\begin{array}{l}\text { Trial with Teleux-Belgium } \\
\text { and LMDS wireless cable } \\
\text { operator CallulaVision USA }\end{array}$ \\
\hline Phasecom & SpeedDemon & $\begin{array}{l}30 \mathrm{Mbps} \text { per } 6 \mathrm{MHz} \\
\text { with } 64 \text { QAM }\end{array}$ & $\begin{array}{l}12.6 \text { Mbps per } 6 \\
\text { MHz with QPSK }\end{array}$ & & $\begin{array}{l}\text { Trials beginning first quarter } \\
\text { of } 1997\end{array}$ \\
\hline Pioneer & Speed Station & $\begin{array}{l}28.5 \mathrm{Mbps} \text { per } 6 \\
\mathrm{MHz} \text { with } 64 \mathrm{QAM}\end{array}$ & $\begin{array}{l}2.6 \mathrm{Mbps} \text { per } 1.3 \\
\mathrm{MHz} \text { with QPSK }\end{array}$ & & $\begin{array}{l}\text { Initial product development } \\
\text { discontinued, plans to build } \\
\text { new product to MCNS specs }\end{array}$ \\
\hline $\begin{array}{l}\text { Scientific- } \\
\text { Atlanta }\end{array}$ & $\begin{array}{l}\text { data Xceller- } \\
\text { ator }\end{array}$ & $\begin{array}{l}6 \mathrm{Mbps} \text { per } 6 \mathrm{MHz} \\
\text { with QBA }\end{array}$ & Talco return & & $\begin{array}{l}\text { Order for } 20,000 \text { units by } \\
\text { TKA Cable }\end{array}$ \\
\hline Terayon & TeraPro & $\begin{array}{l}10 \text { Mbps per } 6 \mathrm{MHz} \\
\text { with S-CDMA }\end{array}$ & $\begin{array}{l}10 \mathrm{Mbps} \text { per } 6 \mathrm{MHz} \\
\text { with S-CDMA }\end{array}$ & $\begin{array}{l}\text { Cisco } \\
\text { Systems, } \\
\text { Sumitomo }\end{array}$ & $\begin{array}{l}\text { Technical trials started in Q } 4 \\
1996 \text { with commercial availa- } \\
\text { bility scheduled in } 1997\end{array}$ \\
\hline Toshiba & Cable Modem & $\begin{array}{l}8 \mathrm{Mbps} \text { per } 6 \mathrm{MHz} \\
\text { channel with QPSK }\end{array}$ & $\begin{array}{l}2 \text { Mbps per } 1.5 \\
\text { MHz channel with } \\
\text { QPSK }\end{array}$ & & $\begin{array}{l}\text { Order for } 50,000 \text { units from } \\
\text { Time Warner Cable }\end{array}$ \\
\hline Zenith & $\begin{array}{l}\text { HomeWorks } \\
\text { Universal }\end{array}$ & $\begin{array}{l}500 \text { kbps or } 4 \mathrm{Mbps} \\
\text { with BPSK }\end{array}$ & $\begin{array}{l}500 \mathrm{kbps} \text { or } 4 \mathrm{Mbps} \\
\text { with BPSK, or } \\
\text { telco return }\end{array}$ & $\begin{array}{l}\text { Cisco } \\
\text { Systems, } \\
\text { US Robotics }\end{array}$ & $\begin{array}{l}\text { Deployed at more than } 300 \\
\text { sites, including trials with } \\
\text { Cox and TCI, and commercial } \\
\text { deployment by Rogers Cab- } \\
\text { lesystems }\end{array}$ \\
\hline
\end{tabular}




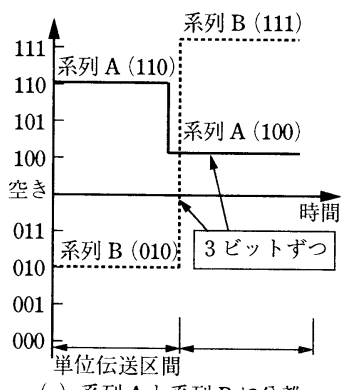

(a) 系列 $\mathrm{A}$ と系列 $\mathrm{B}$ に分離

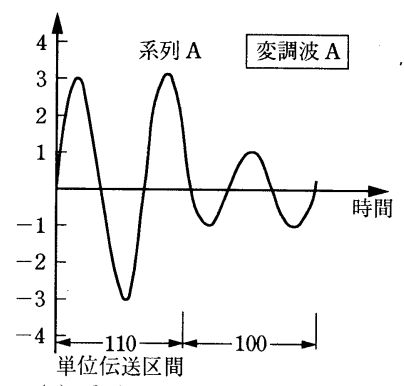

(b) 系列 A から変調波 $\mathrm{A}$ をつくる

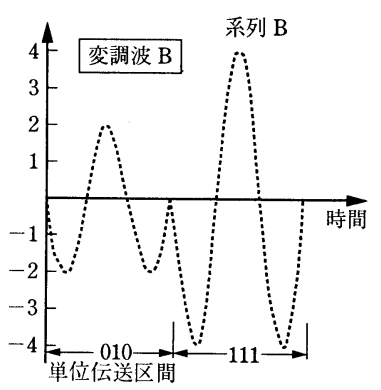

(C) 系列 B から変調波 $\mathrm{B}$ をつくる

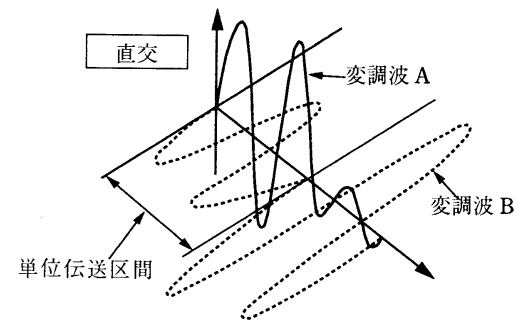

(d) 変調波 A と B を直交化

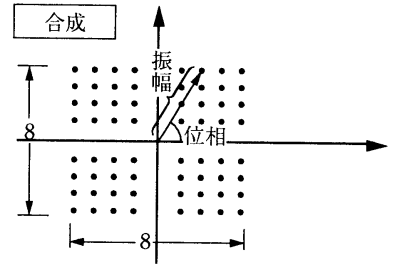

（e）変調波 A とB を合成（64 通りの組合せがある）

図 $264 \mathrm{QAM}$ 方式の原理 ${ }^{3}$

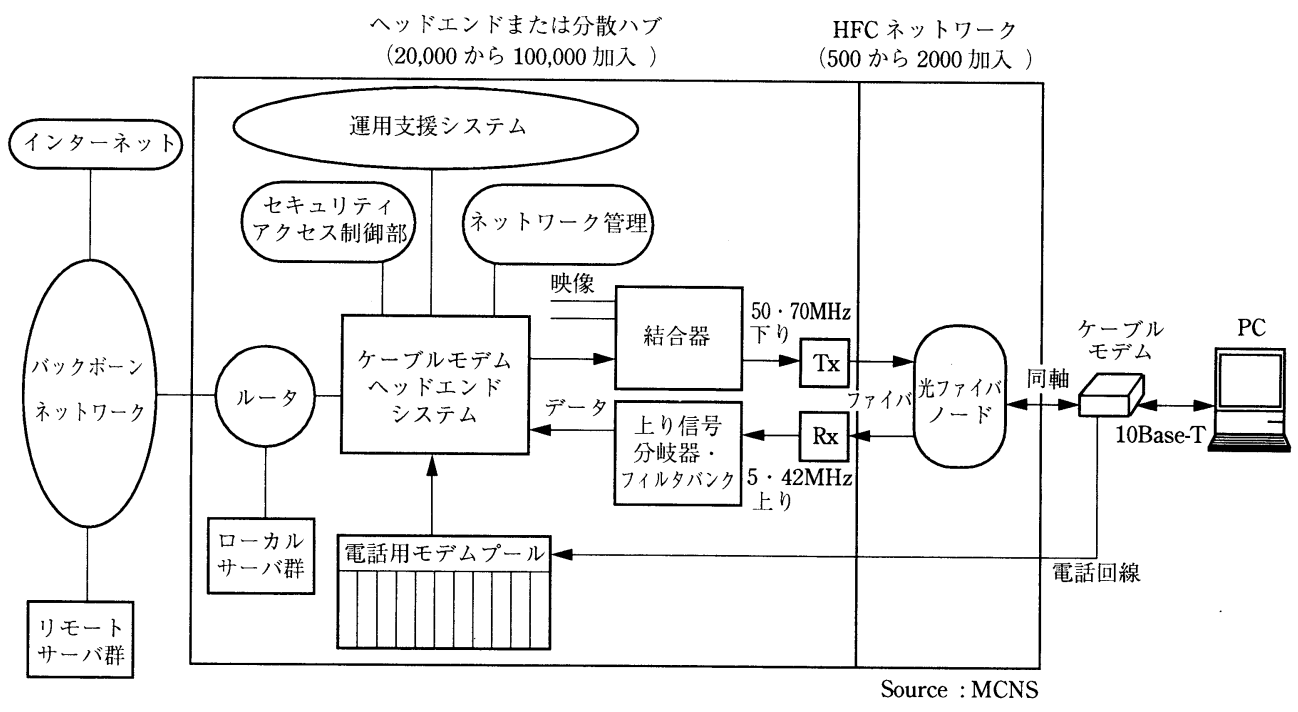

図 3 CATV インターネットシステムの典型的な構成 2

ルータは, IP パケットを調べて, 定められたルー ルに従ってそれらの経路制御を行う装置である。ルー 夕は, Cisco Systems 社やBay Network 社などのべ ンダ製品が主なものである。ルータは多種のプロトコ ルをサポートする企業ネットワーク内で，異なるサー バ・ネットワーク間でデータ交換を行うときに必要と なる。

ヘッドエンドではまた，サーバ，すなわちパソコ
ン, ワークステーションなど, 必要なスケールに依存 するソフトやファイルを格納する装置が必要だが，そ の目的は次の 2 つである.

・1つまたはそれ以上のコンテントサーバは, ロー カルコンテント，たとえばマルチメディア広告， 編集可能な素材デー夕, 電子メール, ネットニュ 一スなどの記憶装置となる。

・非ローカルコンテントを高速にアクセスするため 
に, ほかのサーバのコンテントのローカルコピー を保有するキャッシュサーバや遠隔のコンテント サーバへの直接高速回線とのゲートウェイとなる プロキシサーバとなる.

運用支援システム (OSS) は, ネットワーク上の各顧 客へのサービスの, セットアップ, カットオフ, およ び技術的な監視機能などを提供し, 以下の項目が含ま れる。

・ネットワーク管理

・帯域幅管理

・顧客ケア(利用者・課金管理)

・セキュリティ管理

商用で,このような OSS 機能を供給する装置は, ほとんどがまだフィールドテストの段階である。それ は, IPルータやスイッチング装置の集合体であった り, ボードやカード, モジュールの形態をとることも ある・

ヘッドエンド設備は, ある種のコンピュータなの で，OSが必要である。さまざまなベンダや MSO は， $\mathrm{TCP} / \mathrm{IP}$ をコントロール言語とする 2 つの主要な OS, UNIX と WindowsNTを基本としている.

1996 年 5 月にMicrosoft 社は, Microsoft Software Platform for Public Networks として知られる WindowsNT に基づいたソフトウェアパッケージを 発表したが,これはHFC(Hybrid Fiber/Coax)での OSS 操作を管理するために開発されたソフトウェア である。

CATVオペレータは, OSS 機能を単なるケーブル モデムサービスだけでなく，ケーブル電話，ニア VOD など多様なディジタルサービスと統合したいと 考えている。最終目標は，「エンタプライズマネージ メントシステム」の開発である。

ネットワーク管理は, ネットワークがどのように機 能し, どのような問題が起こり, どう解決しているか に関する管理機能である。これには, 業界標準のシン プルネットワークマネージメントプロトコル (SNMP)が有効で, ケーブルモデムのなかなどネッ トワークの各所に存在する SNMP エージェントがネ ットワークの状態を監視し, SNMP 管理ソフトウエ アパッケージ(例えば, HP 社の OpenView やSun Microsystems 社の NetManagerなど)に結果を送 る.

自動装置によって, あるいは修理を要する場合には 人間に通知するなどして, 訂正操作が必要に応じてと られる。

帯域幅管理 (RF スペクトル管理とも呼ばれる)は,
トラフィックに応じて, どのサービスに, ファイバや 同軸上のどの周波数スペクトルを割り当てるのかを決 定する機能のことである.ダイナミックに効率的な管 理機能が求められる.

顧客ケアシステムは, 要求に応じたサービス品質を 管理し，オーダ処理や課金処理を行うシステムであ る.ユーザによって帯域保証型のプレミアムサービス と他ユーザとの競合状況で帯域が決定されるべストエ フォートサービスとが考えられる。また，トラブル時 のヘルプデスクシステムなども含まれる.

\section{4. ケーブルモデムの標準化動向}

公式の標準化団体として最初にケーブルモデムの標 準化活動を開始したのは IEEE 802.14 のワーキンググ ループであった．この IEEE 802.14 の主なメンバは, HP, Zenith, GI などのケーブルモデムベンダ，および Stanford Telecom などの部品ベンダだが, 70 社以上 のメンバによって 1995 年初頭から開始したわりには, 調整作業が遅れ, 標準仕様の完成は, 1997 年後半に なる見込みである。慣例的には, IEEE 802 標準は, ISO 標準となる.

一方，オペレータ主導の標準化作業は, CableLabs の過去 3 年の活動成果がもととなっている. CableLabs は 1995 年 4 月に高速ケーブルデータサービス (HSCDS)ついての提案依頼書 (RFP) を出した.これ は，どうすればエンドッーエンドの配信システムある いは配信システムの一部分がつくりだせるかをベンダ に投げかけたものだった。

この取り組みをリードしたのは, TCI, Time Warner, Viacom, Comcast, Continental, Cox, Jones とい ったアメリカの代表的なオペレータと, Rogersと Shaw というカナダの 2 大オペレータである.

RFP の目的の中に 2 つ標準インタフェース仕様 の決定があった．それはネットワークの先端部分であ るインターネットバックボーンとの結合部分と, パソ コンとの接続部分のインタフェースについてである. その間にはさまざまなアプローチをとる余地が残され ている. 最初の仕様としてはネットワークの 2 つ下 位層に目が向けられており, 国際標準化機構(ISO)の 「プロトコルスタック」と呼ばれる 7 層の中の物理層 (PHY) とデータリンク層の中の媒体アクセス制御 (MAC) 層に関するものである.

また, この RFPでは, ケーブルオペレータにとっ て鍵になるいくつかのビジネス目標を明らかにしたと いえる。例えば，2つのサービスクラスを供給する道 をオペレータに対して示している.ひとつはプレミア 
表 2 MCNS モデムの仕様2)

\begin{tabular}{l|l|l}
\hline \hline & \multicolumn{1}{|c}{ Downstream } & \multicolumn{1}{c}{ Upstream } \\
\hline Modulation Technique & $64 / 256 \mathrm{QAM}$ & QPSK and QAM \\
\hline Raw Data Throughput & $30 \mathrm{Mbps}$ per $6 \mathrm{MHz}$ for $64 \mathrm{QAM}$ & $1.6 \mathrm{Mbps}$ per $1 \mathrm{MHz}$ for QPSK \\
& $40 \mathrm{Mbps}$ per $6 \mathrm{MHz}$ for $256 \mathrm{QAM}$ & $3.2 \mathrm{Mbps}$ per $1 \mathrm{MHz}$ for $16 \mathrm{QAM}$ \\
\hline Data Throughput with & $27 \mathrm{Mbps}$ per $6 \mathrm{MHz}$ for $64 \mathrm{QAM}$ & $1.4 \mathrm{Mbps}$ per $1 \mathrm{MHz}$ for QPSK \\
Forward Error Correction & $36 \mathrm{Mbps}$ per $6 \mathrm{MHz}$ for 256 QAM & $2.4 \mathrm{Mbps}$ per $1 \mathrm{MHz}$ for $16 \mathrm{QAM}$ \\
\hline
\end{tabular}

ム料金を徵収してデータのスループットを保証するサ ービスであり，もうひとつは容量を多くのユーザーと 分け合うことによる安い料金のベストエフォート型サ 一ビスである。また，それはベンダに対して，ぞうや つて周波数を効率的に割り当てたり, 音声伝送装置, 双方向ビデオ会議などの先進的な機能をサポートする 配信システムを提供しょうとしているかについて提案 するように求めている，RFPにはベンダから約 50 の 回答を得た。

コロラド州のキーストンで行われた 1995 年の 8 月 の会議で, CabalLabs はCATV オペレータのメンバ 企業にベンダからの提案や期待するプロトタイプの機 器評価についての意見を求めた。そのなかには製品が 入手可能になるまでのタイムテーブル, 簡潔な構成, 帯域の有効利用やセキュリティといったことが含まれ ていた。

CableLabs は 1995 年末, 主要なケーブルネット 95 の展示会(カリフォルニア州のアナハイムのウエス夕 ンケーブルショー)でネットワーキングの機器やデー 夕に合わせたアプリケーションのデモンストレーショ ンを行うために，約 40 のベンダを集めた．

そして, 1996 年に入ってすぐに, ケーブルモデム の開発と標準化を進めるためのケーブルオペレータの 協調行動の中心は，以下に述べるグループとしての Multimedia Cable Network Systems Partners Ltd. (MCNS)にシフトしていったのである.

TCI, TimeWarner, Cox, Comcast の 4 つの MSO (Multiple System Operator, 複数の CATV 局を運営 する統轄会社)が連合して 1996 年 2 月に結成された MCNS (Multimedia Cable Network System Partners）には,さらに Rogers(カナダ) と CableLabs (全米の MSO の共同利用研究機関) とが加わり, オぺ レータ主導の統一調達仕様としてのケーブルモデム仕 様を 1996 年 3 月 16 日に確定した。この結果, 1998 年前半には, MCNS 仕様に統一した, ケーブルモデ ムを前提にしたサービスを行うと MCNS メンバのオ ペレータは表明している.さらに, Cable Labsを中
心に ITU-T SG 9 での標準化への働きかけが行われ ており, ITU-T 標準になる見通しである。

MCNSの主な仕様は, 表 2 に示すように，下りに 64/256 QAM, また，上りにQPSK および16 QAM を 用いている。

この他に DAVIC (Digital Audio-Visual Council) もケーブルモデムの標準化をあげていたが, 基本的に は ITU-T SG 9 などに追従する見込みである.

\section{5. ケーブルインターネットの市場動向}

ケーブルインターネットサービスは, 電気通信法の 緩和によって可能になった CATV オペレータの新通 信サービスの目玉として位置づけられる。すでに 1996 年 1 月から Jones Internet Channel, 9 月から @ Home とRoad Runnerのサービスが始まってい る.このサービスには前述のように双方向の HFC 化 がポイントとなるが，ケーブルインターネットサービ スに熱心なオペレータは, 1997 年から 1998 年にかけ て急速な HFC 化を進めている.

表 3 に, 1997 年から 1998 年にかけての HFC 化の 計画を示す。またこのような $\mathrm{HFC}$ 化を前提にした 市場の予測を図 4 に示す。

このように,アメリカでも従来は10\%程度でしか なかった双方向 CATVも, 新通信サービスへ向けて 30\%以上の HFC に上る双方向化率を達成するオペレ ー夕が多くなっている.図 4 では, 1997 年末で約 2

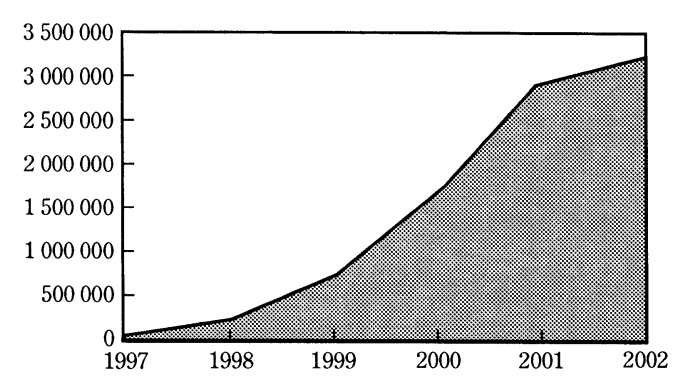

図 4 CATV インターネットの加入者数予測 22 
表 3 北米における $\mathrm{HFC}$ 化計画 ${ }^{2)}$

\begin{tabular}{l|l|c|c|c|c}
\hline \hline \multicolumn{1}{c|}{ Cable Operator } & Service Name & $\begin{array}{l}\text { HSCDS 2-Way } \\
\text { Homes Passed } \\
\text { February 1997 }\end{array}$ & $\begin{array}{l}\text { 2-Way HSDCS Homes } \\
\text { Passed as of Cable } \\
\text { Homes passed }\end{array}$ & $\begin{array}{l}\text { HSCDS 2-Way } \\
\text { Homes Passed } \\
\text { January 1998 }\end{array}$ & $\begin{array}{l}\text { 2-Way HSDCS Homes } \\
\text { Passed, as Cable } \\
\text { Homes Passed }\end{array}$ \\
\hline Time Warner & Road Runner & 580,000 & $3.2 \%$ & $4,500,000$ & $25.0 \%$ \\
\hline USWest/Continental & Highway 1 & 290,000 & $3.6 \%$ & $1,500,000$ & $18.7 \%$ \\
\hline Rogers & WAVE & 213,000 & $8.1 \%$ & $1,500,000$ & $57.6 \%$ \\
\hline Videotron & WAVE & 200,000 & $13.3 \%$ & 400,000 & $26.6 \%$ \\
\hline COGECO & WAVE & 195,000 & $21.6 \%$ & 300,000 & $33.3 \%$ \\
\hline Adelphia & Power Link & 192,000 & $7.6 \%$ & 400,000 & $16.0 \%$ \\
\hline TCI & $@$ Home & 80,000 & $0.3 \%$ & $1,500,000$ & $6.2 \%$ \\
\hline GTE & Americast & 40,000 & $36.3 \%$ & 135,000 & $36.3 \%$ \\
\hline Cox & $@$ Home & 30,000 & $0.6 \%$ & $1,500,000$ & $30.0 \%$ \\
\hline Comcast & $@$ Home & 25,000 & $0.3 \%$ & $1,000,000$ & $14.7 \%$ \\
\hline Shaw & WAVE & 20,000 & $1.1 \%$ & 265,000 & $14.7 \%$ \\
\hline Cablevision Systems & Optimum Online & 15,000 & $0.3 \%$ & 350,000 & $8.7 \%$ \\
\hline Jones Intercable & Internet Channel & 12,000 & $0.7 \%$ & 60,000 & $3.5 \%$ \\
\hline Other & & 113,700 & - & 250,000 & - \\
\hline TOTAL & & $2,005,700$ & & $13,660,000$ & \\
\hline
\end{tabular}

万世帯がケーブルインターネットサービスに加入し , 2000 年に 160 万世帯, そして 5 年後には 300 万世帯 を超えるものと予測されている。

ヨーロッパでは, CATV 普及率の高いドイッ, 心゙ ルギーなどベネルクス地域，およびイギリスにおい て, 商用実験サービスが始まっており, 間もなく @ Home などの事業が開始されようとしている.

\section{6. むすび}

ケーブルインターネットは, インターネットのボト ルネックであるアクセス系の問題を解消する上で, ADSL と共に最も現実的な解として期待されている. そして欧米, 特にアメリカでは, 先に述べたように, すでに TCI をはじめとする MSO 連合の@Homeや， TimeWarner 社の Road Runner などの商用サービス が開始され，加入者が急速に増加している．解決すべ き技術課題や通信事業の経験のないCATV オペレー 夕の事業構造などの課題も多いが, 伝送速度で電話線
の 100 倍以上, コストで約 10 分の 1 も可能なサービ スである.今後の発展が大いに期待される分野であ る。

(1997 年 7 月 4 日受付)

\section{〔参 考 文 献〕}

1）藤原：“技術解説シリーズ(2)”，CATVnow，42，pp. 30-35, NHK ソフトウェア（May 1997）

2) Kinetic Strategies, Inc. Report

3）藤原, 大久保: “インターネット時代の画像圧縮技術”, アス キー (Aug. 1996)

4）中川, 藤原監訳: “高速インターネットとケーブルモデム”, アスキー (Oct. 1996)

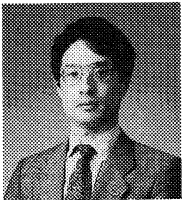

藤劰洋 1977 年, 京都大学理学部卒 業.コンピュータメーカ, エンジニアリング 会社を経て, 1985 年, (株)アスキーに入社. 1993 年, (株)グラフィックス・コミュニケ ーショシ・ラボラトリーズに出向, 常務取締 役研究開発本部長となり, 現在に至る.コン ピュー夕通信システム, 画像符号化技術の研 究開発に従事. 工学博士. 正会員. 